OPEN ACCESS

Edited by:

Feng Yang,

China University of Geosciences

Wuhan, China

Reviewed by:

Ruyue Wang,

SINOPEC Petroleum Exploration and Production Research Institute, China

Wei Dang,

Xi'an Shiyou University, China Yang Wang,

China University of Mining and Technology, China

*Correspondence:

Lei Chen

chenlei19880804@163.com

Specialty section:

This article was submitted to

Economic Geology,

a section of the journal

Frontiers in Earth Science

Received: 23 June 2021

Accepted: 03 August 2021

Published: 15 September 2021

Citation:

Zhang $Y$, Li R, Huang $H$, Gao $T$, Chen L, Zhao B, Wu $X$ and Khaled $A$

(2021) The Origin of Silica of Marine Shale in the Upper Ordovician Wulalike Formation, Northwestern Ordos Basin,

North China.

Front. Earth Sci. 9:729710.

doi: 10.3389/feart.2021.729710

\section{The Origin of Silica of Marine Shale in the Upper Ordovician Wulalike Formation, Northwestern Ordos Basin, North China}

\author{
Yanni Zhang ${ }^{1}$, Rongxi $\mathrm{Li}^{1,2}$, Hexin Huang ${ }^{1,2}$, Tian Gao ${ }^{3}$, Lei Chen ${ }^{4,5 *}$, Bangsheng Zhao ${ }^{1}$, \\ Xiaoli $W^{1,2}$ and Ahmed Khaled ${ }^{1}$ \\ ${ }^{1}$ School of Earth Science and Resources, Chang'an University, Xi'an, China, ${ }^{2}$ Key Laboratory of West Mineral Resources and \\ Geological Engineering of Ministry of Education, Chang'an University, Xi'an, China, ${ }^{3}$ Gas Production Plant, PetroChina Changqing \\ Oilfield Company, Xi'an, China, ${ }^{4}$ Shandong Provincial Key Laboratory of Deep Oil and Gas, Qingdao, China, ${ }^{5}$ School of \\ Geosciences, China University of Petroleum (East China), Qingdao, China
}

The shale of the Wulalike Formation developed in the northwestern Ordos Basin is considered to be an effective marine hydrocarbon source rock. One of the key factors for successful shale gas exploration in the Wufeng-Longmaxi Formation in the Sichuan Basin is the high content of biogenic silica. However, few people have studied the siliceous origin of the Wulalike shale. In this study, we used petrographic observation and element geochemistry to analyze the origin of silica in the Wulalike shale. The results show that the siliceous minerals are not affected by hydrothermal silica and mainly consist of biogenic and detrital silica. A large number of siliceous organisms, such as sponge spicules, radiolarians, and algae, are found under the microscope. It has been demonstrated that total organic carbon has a positive correlation with biogenic silica and a negative correlation with detrital silica, and biogenic silica is one of the effective indicators of paleoproductivity. Therefore, the enrichment of organic matter may be related to paleoproductivity. Through the calculation of element logging data in well $A$, it is found that biogenic silica is mainly distributed in the bottom of the Wulalike Formation, and the content of biogenic silica decreases, while the content of detrital silica increases upward of the Wulalike Formation. Biogenic silica mainly exists in the form of microcrystalline quartz, which can form an interconnected rigid framework to improve the hardness and brittleness of shale. Meanwhile, biogenic microcrystalline quartz can protect organic pores from mechanical compaction. Therefore, it may be easier to fracture the shale gas at the bottom of the Wulalike Formation in well $A$.

Keywords: Ordos Basin, Wulalike formation, origin of silica, biogenic silica, siliceous organisms

\section{INTRODUCTION}

The study of the origin of silica began in the 20th century. Adachi et al. (1986) proposed the hydrothermal model of siliceous rocks near the mid-ocean ridge and believed that the siliceous rocks came from deep-water sediments. At this time, it was emphasized that the siliceous minerals came from terrigenous clasts and submarine hydrothermal fluids (Hein, 1987; Campbell et al., 1988). Harrover and Norman (1982) discovered the sedimentary black chert and opals in Devonian in 
Texas, United States. Schieber et al. (2000) studied the quartz in the late Devonian black shale in the eastern United States and found that almost all quartz came from plankton and the same characteristics were found in Barnett shale, Woodford shale, and Marcellus shale. Shale gas has been explored and developed in China for nearly 20 years. At present, three major shale gas fields have been developed in southern China, and the marine shale gas of Wufeng-Longmaxi Formation in the Sichuan Basin is under the stage of commercial development and mainly comes from adsorbed gas (Yang et al., 2017; Chen et al., 2019a; Gou and Xu, 2019; Wang et al., 2019). The current experience shows that one of the key factors for successful shale exploration is the high content of biogenic silica and adsorbed gas in this area (Liu et al., 2011; Guo, 2014; Chen et al., 2019b; Dong et al., 2019; Yang et al., 2021). At present, the research mainly focuses on the adsorption capacity of shale reservoir (Chen et al., 2019b; Chen et al., 2020; Huang et al., 2020a; Wang et al., 2020; Wei et al., 2021), while the origin and mechanical properties of siliceous materials are rarely studied.

Modern petrological studies show that the content of brittle minerals represented by quartz is usually more than $45 \%$ in shale (Loucks and Ruppel, 2007; Liu et al., 2011; Wang et al., 2021). Quartz is an important factor that affected the fracturing ability and induced fracture morphology of shale. The higher the content of quartz, the better the fracturing ability of shale. Further research shows that there is a high positive correlation between siliceous minerals and TOC content in the high-quality shale of the Wufeng-Longmaxi formation, that is, the higher the content of siliceous minerals, the higher the content of organic carbon (Yang et al., 2016; Dong et al., 2019; Khan et al., 2019); at the same time, it is found that the content of siliceous minerals is positively correlated with the gas and porosity of shale (Yang et al., 2016; Dong et al., 2019; Xu et al., 2019), suggesting that siliceous minerals are of great significance for the generation and exploration of shale gas in this area. Therefore, it is very important to clarify the origin of quartz for reservoir brittleness evaluation, gas bearing evaluation, and development potential evaluation of shale (Dong and Harris, 2020; Qiu et al., 2020). With the vigorous development of shale gas in the world, many scholars focus their aims on the origin of quartz in shale (Milliken et al., 2012; Milliken et al., 2016; Li et al., 2019; Joseph et al., 2020; Xu et al., 2021). Milliken et al. (2016) classified quartz in Barnett shale into extrabasin clastic quartz, intrabasin clastic quartz, and authigenic quartz. Yang et al. (2018) divided the quartz in Longmaxi Formation siliceous shale into clastic silica, diagenetic silica, and biogenic silica and the quartz in argillaceous shale into clastic silica and diagenetic silica. Qiu et al. (2020) classified quartz into six types: detrital quartz, recrystallized radiolarians, siliceous fossil fragments, microcrystalline quartz, quartz secondary enlargement, and hydrothermal quartz veins. Although the classification of quartz is confusing and different scholars have different understanding, the quartz is mainly divided into three types in marine shale: 1) terrigenous detrital quartz; 2) hydrothermal quartz, the quartz formed by hydrothermal fluids erupted from
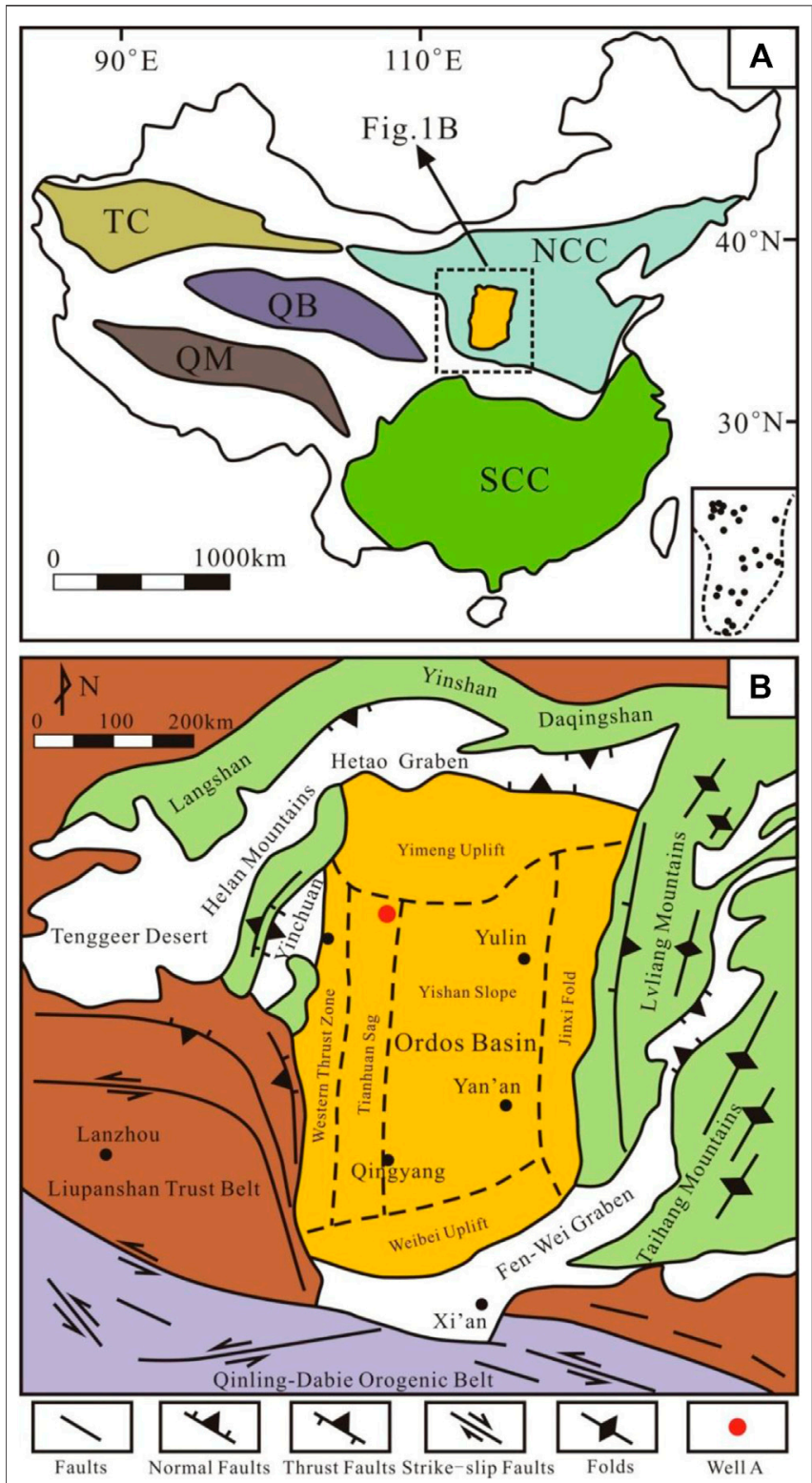

FIGURE 1 | (A) Major tectonic plates in China. NCC: North China Craton, SCC: South China Craton, TC: Tarim Craton, QB: Qaidam Block, and QM: Qiangtang Massif. (B) Simplified structural map of the Ordos Basin and its adjacent areas. Modified from Ritts et al. (2004).

the seabed (Adachi et al., 1986; Beauchamp and Baud, 2002; He et al., 2016); and 3) biogenic quartz. It refers to quartz formed by diagenesis of siliceous paleontology. The organisms generally refer to diatoms, radiolarians, and sponge spicules (Boggs, 2006; Day-Stirrat et al., 2010; Joseph et al., 2020; Guan et al., 2021). At present, it is found that biogenic silica in shale is not only related to the enrichment of organic matter (Dong et al., 2019; Khan et al., 2019; Li et al., 2019) but also can promote the mechanical properties and pore preservation of shale reservoir (Yang et al., 2018; Dong et al., 2019; Dong and Harris, 2020; Qiu et al., 2020; Xu et al., 2021), so it is very 
urgent to study the origin of silica for shale gas exploration and development.

In recent years, the risk exploration of Ordovician in the western Ordos Basin of the Changqing Oilfield has found natural gas continuously. Nine wells (Zhong 2, E 102, Na 1, Zhong Ping 1, Qi Tan 2, Zhong Tan 2, Liang Tan 1, Yin Tan 1, and E 99) have seen gas anomalies obviously in the thick shale at the bottom of the Wulalike Formation, eight wells have obtained low gas production, and Zhong 4 well has obtained $4 \times 10^{4} \mathrm{~m}^{3} / \mathrm{d}$ industrial gas in the Wulalike Formation, proving that effective marine hydrocarbon source rock is developed in the western basin. Previous studies on the Ordovician Wulalike Formation mainly focused on sedimentary facies, reservoir, and hydrocarbon generation potential in the western basin (Wu et al., 2015; Wang et al., 2017; Xiao et al., 2017; Wu et al., 2020). The Wulalike shale in well A in the northwestern Ordos Basin contains a high content of quartz. A large number of siliceous paleontology, such as sponge spicules and radiolarians, are found under the microscope. Therefore, in this study, we used petrographic observation and element geochemistry, coupled with the logging curve to analyze the origin of silica in well A shale in the Wulalike Formation, so as to establish the basis for further exploration in the northwestern Ordos Basin.

\section{GEOLOGICAL SETTING}

The Ordos Basin is an important oil and gas-bearing basin located in the west of the North China Plate, with an area of about $25 \times$ $10^{4} \mathrm{~km}^{2}$ (Lee, 1986) (Figure 1A). The basin is composed of six secondary structural units: Yimeng Uplift, Jinxi Fold, Yishan Slope, Tianhuan Sag, the Western Thrust Zone, and Weibei Uplift (Figure 1B). The Ordos Basin is a multicycle superimposed basin developed on the Archean-Paleoproterozoic metamorphic basement. In the early Paleozoic, the basin was adjacent to the ancient Qinling Sea in the south and the ancient Qilian Sea and the ancient Helan Sea in the west. It is located in the northeast of the Qinling-Qilian-Helan trigeminal rift system and belongs to the southwest margin of the North China platform (Zeng et al., 2021; Lin et al., 1995; Huang et al., 2020b). The western margin of the basin is located between the Ordos platform and the ancient Qinling Sea, with the property of passive continental margin. In the Ordovician, it was in a relatively depressed tectonic position. Affected by the Qinling-Qilian-Helan trigeminal rifts, the western Ordos Basin developed a "regenerated" Helan aulacogen with inherited activities in the early Ordovician (Wang et al., 2005). During the middle and late Ordovician, the basin uplifted as a whole due to the collision between the Qilian-Qinling Paleoocean Basin and the North China Plate. In the middle and late Ordovician, affected by the collision between the Qilian-Qinling Paleoocean Basin and the North China Plate, the basin uplifted as a whole, the central and eastern basin were eroded, and the western and southern margins subsided rapidly. A set of deep-water sediments were developed, including siliceous shale, silicite, and a small amount of carbonates (Fu and Zheng, 2001; Wu et al., 2015). In the late Ordovician, influenced by the northward subduction of the Qinqi oceanic plate, the main part of the North China platform

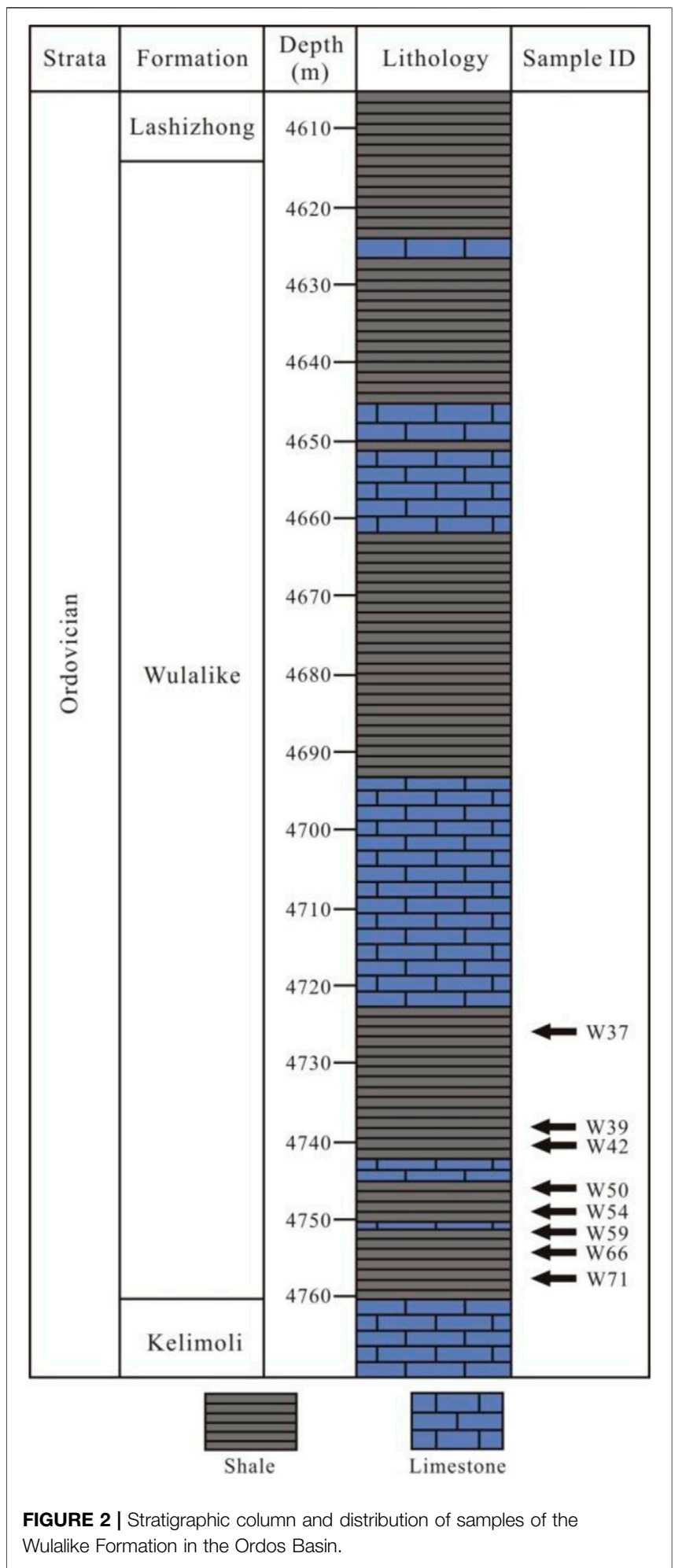

including the Ordos Basin and its western Helan depression uplifted to the surface, ending its early Paleozoic marine sedimentations ( $\mathrm{Xu}$ et al., 2006; Yang et al., 2011).

The Ordovician in the western margin of the basin can be classified into the Sandaokan Formation, the Zhuozishan 


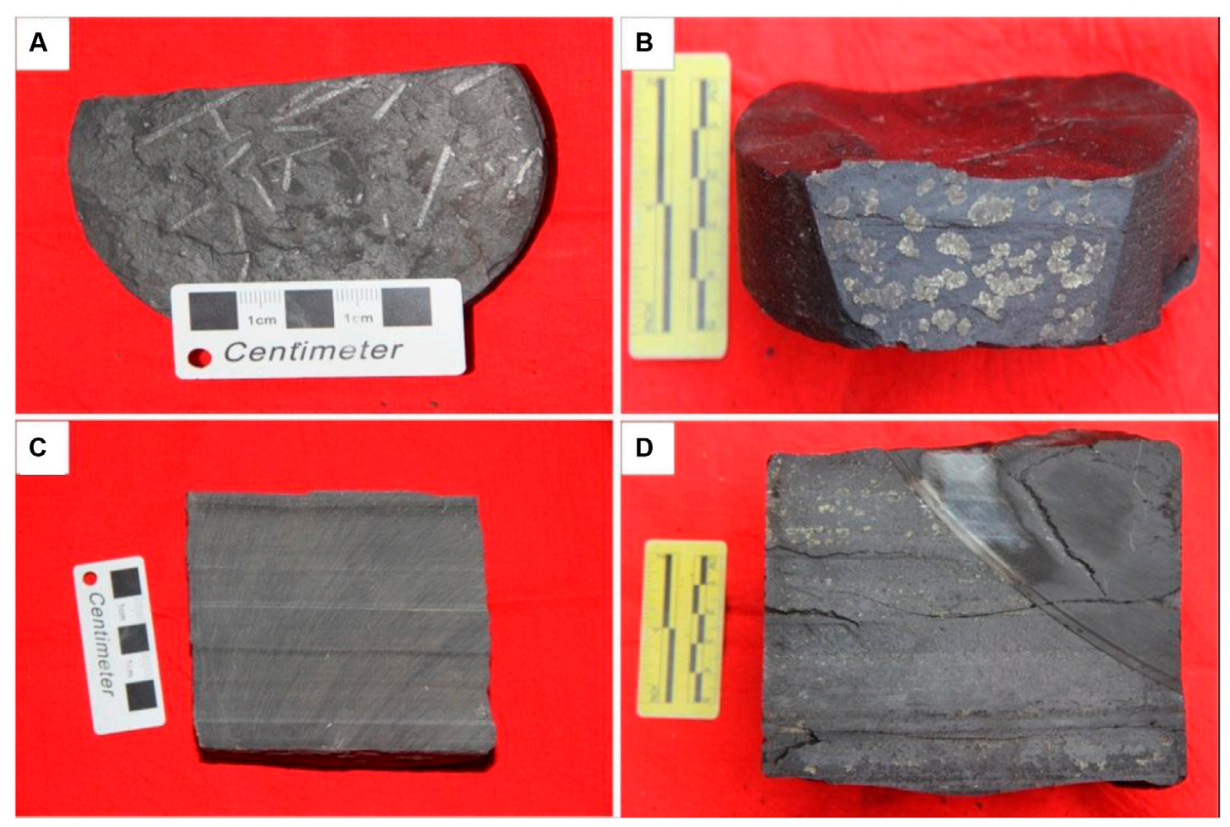

FIGURE 3 | The features of the Wulalike shale. (A) The shale with graptolite fossils, 4,755.2 m. (B) Many pyrites can be seen in the shale, 4,758.4 m. (C) The horizontal bedding in the shale core, 4,730.5 m. (D) The fractures are developed in shale, 4,735.6 m.

Formation, the Kelimoli Formation, the Wulalike Formation, and the Lashizhong Formation from the bottom to top. The Sandaokan-Zhuozishan Formation is mainly an opened platform facies, consisting mainly of dolomite and marlite; the Kelimoli Formation is a platform margin slope facies, with wormhole limestone, marl intercalated with micrite limestone, and black shale, and is rich in biological fossils (Wu et al., 2015). During the deposition of the Wulalike Formation, the central and eastern parts of the basin were uplifted to the surface and the water in the west was further deepened, which were slope and basin facies, respectively. The slope facies was dominated by limestone (Ma et al., 2013). A layer of gray calcareous breccia developed at the bottom of the basin, and the lithology of the middle and upper parts was thin black shale rich in graptolite and other biological fossils. The depositional pattern of the Wulalike Formation was inherited in the middle Lashizhong stage. The water depth in the western region deepened again and the basin facies scope enlarged, while the slope facies scope narrowed. The basin facies is dominated by carbonaceous shale intercalated with thin sandstone, and the slope facies is dominated by micritic limestone and argillaceous limestone (Ma et al., 2013; Hou et al., 2021). Well A in the study is located in the slope facies. The lithology of the Wulalike Formation is mainly shale with thickly layered limestone (Figure 2).

\section{SAMPLES AND METHODS}

The samples in this study are from the upper Ordovician Wulalike Formation shale of well A in the northwestern Ordos Basin (Figure 2). All the samples are analyzed by TOC and major elements. The TOC analysis was conducted at the Key Laboratory of Exploration Technologies for Oil and Gas Resources, Ministry of Education, Yangtze University, China, and a major element analysis was carried out at the Key Laboratory of Western Mineral Resources and Geological Engineering, Ministry of Education, Chang'an University, China. Some paleontological fossils were selected for scanning electron microscope (SEM) and energy dispersive spectrometer (EDS) analysis. The experiment was carried out in the State Key Laboratory of continental dynamics, Northwest University, China.

For the total organic carbon (TOC) analysis, after the samples were crushed to about 200 mesh of powder, $0.1 \mathrm{~g}$ was weighed and pretreated with $10 \%$ dilute hydrochloric acid to remove the inorganic carbon in the sample and then dried at $60-80^{\circ} \mathrm{C}$. The treated samples were washed with distilled water to remove the residual hydrochloric acid, and then the samples were fully burned in the oxygen flow at $1,200^{\circ} \mathrm{C}$ so that all organic carbon was converted into inorganic carbon dioxide. The volume of $\mathrm{CO}_{2}$ was measured by a Leco CS- 400 carbon sulfur analyzer to estimate the TOC content, and the analysis uncertainty was less than $0.1 \%$.

For a major oxide analysis, after crushing and sieving each sample to 200 mesh, the samples were dried in a $105^{\circ} \mathrm{C}$ oven for $2 \mathrm{~h}$ to make the samples fully dry firstly. $1 \mathrm{~g}$ dry sample was weighed and placed in a ceramic crucible, burned in a muffle furnace at $1,000{ }^{\circ} \mathrm{C}$, cooled to room temperature, and then weighed to calculate the loss on ignition (LOI). Weigh $0.5 \mathrm{~g}$ dry sample, mix $5 \mathrm{~g}$ anhydrous lithium tetraborate (cosolvent) and $0.3 \mathrm{~g}$ ammonium nitrate (oxidant) evenly, put them together in a platinum crucible, heat them in a sample melting furnace at 

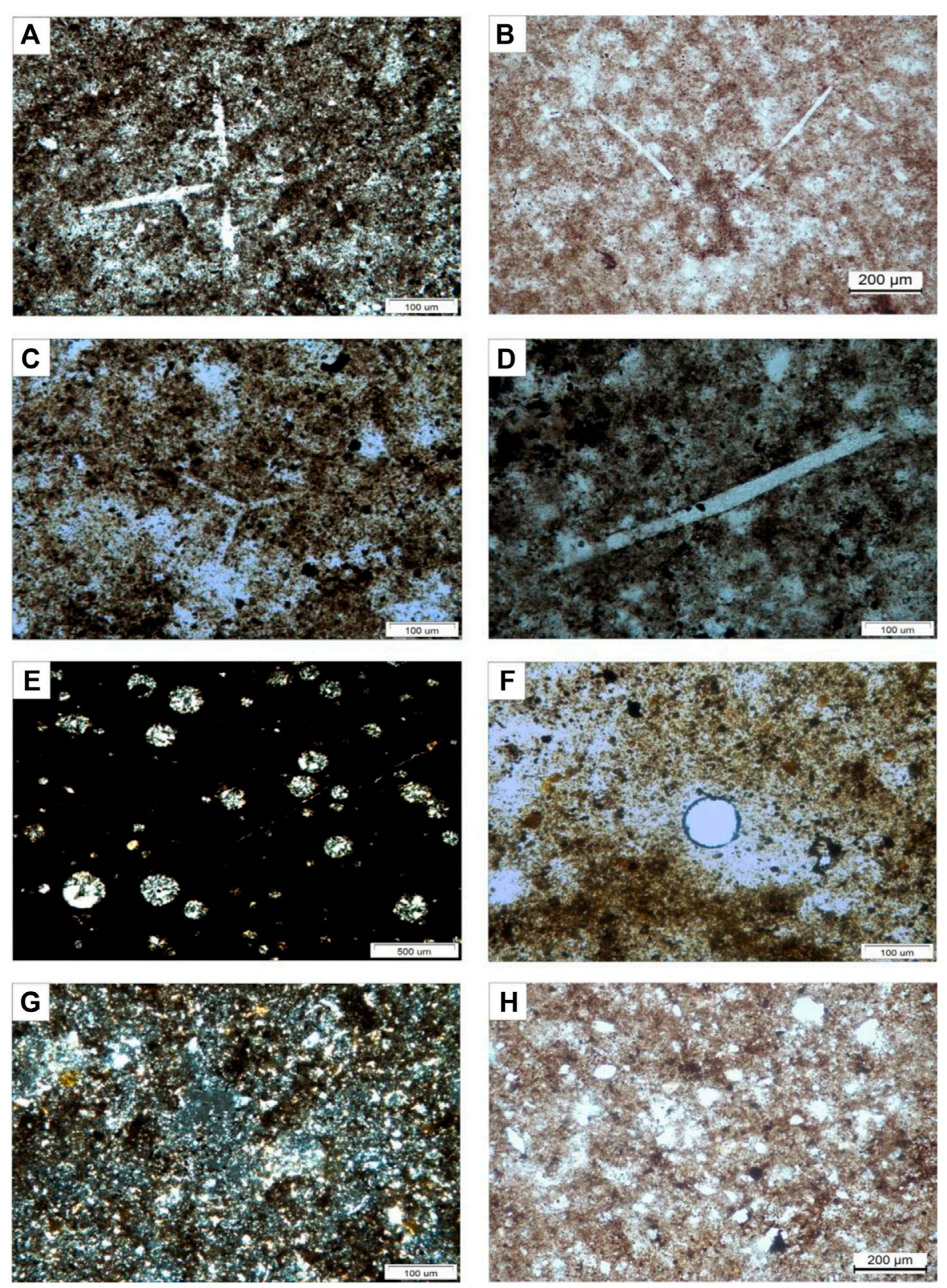

FIGURE 4| The features of quartz under the microscope. (A) is a complete radiolarian, basically, 4,758.0 m, plane-polarized light. (B) The radiolarian has been destroyed and only has its spines, 4,756.5 m, plane-polarized light. (C) The sponge has three spines, 4,755.2 m, plane-polarized light. (D) This sponge species with one direction is the most abundant in the Wulalike Formation, 4,755.0 m, plane-polarized light. (E) Many algae exist in one field of view, most of which are $200 \mu \mathrm{m}$ in diameter, 4,748.6 m, cross-polarized light. (F) The algae are surrounded by organic matter, 4,747.5 m, plane-polarized light. (G) Fine-grained microcrystalline quartz is in dark blue, which has an amorphous form, 4,732.0 m, cross-polarized light. (H) The detrital quartz is subangular and has poor sorting property, 4,730.5 m, planepolarized light.

$1,100^{\circ} \mathrm{C}$ for $12 \mathrm{~min}$, pour out the melt to form a flat glass sheet, and then carry out the XRF test. In the test, the Shimadzu sequential scanning Lab Center XRF-1800 X-ray fluorescence spectrometer was used to monitor the test results, and the relative error was less than $5 \%$.

Select fresh shale samples with a flat and smooth surface, mechanically grind the shale surface with a Leica TXP fine grinding machine, and put the polished sheet into a Leica
RES102 ion thinning instrument for argon ion polishing, that is, bombard the sample surface with argon ion, of which the working voltage is $5 \mathrm{kV}$ and the current is about $2.2 \mathrm{~mA}$. After polishing, the sample surface is treated with a gold plating film. Then, the micromorphology of shales was observed by a Quanta250 FEG field emission environmental scanning electron microscope. The working parameters were set as follows: voltage at $20 \mathrm{kV}$, working distance at $7.525 \mathrm{~mm}$, and 
TABLE 1 | TOC and major oxide contents (wt\%) of the shale samples.

\begin{tabular}{|c|c|c|c|c|c|c|c|c|c|c|c|c|c|c|}
\hline Sample ID & Depth(m) & TOC & $\mathrm{SiO}_{2}$ & $\mathrm{TiO}_{2}$ & $\mathrm{Al}_{2} \mathrm{O}_{3}$ & $\mathrm{TFe}_{2} \mathrm{O}_{3}$ & MnO & MgO & $\mathrm{CaO}$ & $\mathrm{Na}_{2} \mathrm{O}$ & $\mathrm{K}_{2} \mathrm{O}$ & $\mathrm{P}_{2} \mathrm{O}_{5}$ & LOI & Total \\
\hline W37 & $4,726.10$ & 0.91 & 47.95 & 0.55 & 12.08 & 3.41 & 0.01 & 2.36 & 11.51 & 0.44 & 5.48 & 0.13 & 15.73 & 99.65 \\
\hline W39 & $4,738.65$ & 0.70 & 48.75 & 0.52 & 10.48 & 4.75 & 0.02 & 4.38 & 11.08 & 1.97 & 3.40 & 0.10 & 15.00 & 100.45 \\
\hline W42 & $4,740.55$ & 1.02 & 61.57 & 0.39 & 9.34 & 3.28 & 0.03 & 2.54 & 8.26 & 0.51 & 2.99 & 0.41 & 10.58 & 99.90 \\
\hline W50 & $4,746.82$ & 1.03 & 56.57 & 0.38 & 8.89 & 4.07 & 0.01 & 1.84 & 10.81 & 1.38 & 3.06 & 0.19 & 12.51 & 99.71 \\
\hline W54 & $4,748.84$ & 1.07 & 64.82 & 0.43 & 9.79 & 3.12 & 0.01 & 2.81 & 5.69 & 0.81 & 3.70 & 0.08 & 9.57 & 100.83 \\
\hline W59 & $4,751.73$ & 1.07 & 64.43 & 0.26 & 6.24 & 1.91 & 0.01 & 1.30 & 10.67 & 0.69 & 2.72 & 0.10 & 11.47 & 99.80 \\
\hline W66 & $4,754.43$ & 1.30 & 60.40 & 0.33 & 7.02 & 2.31 & $<0.01$ & 1.35 & 12.09 & 0.83 & 3.05 & 0.06 & 12.70 & 100.14 \\
\hline W71 & $4,757.34$ & 1.16 & 56.29 & 0.20 & 4.86 & 1.70 & 0.01 & 1.75 & 16.07 & 0.70 & 2.29 & 0.06 & 16.20 & 100.13 \\
\hline Avg & & 1.03 & 57.60 & 0.38 & 8.59 & 3.07 & 0.01 & 2.29 & 10.77 & 0.92 & 3.34 & 0.14 & 12.97 & 100.08 \\
\hline UCC & & - & 66.00 & 0.64 & 15.40 & 5.04 & 0.10 & 2.48 & 3.59 & 3.27 & 2.80 & 0.15 & - & - \\
\hline
\end{tabular}

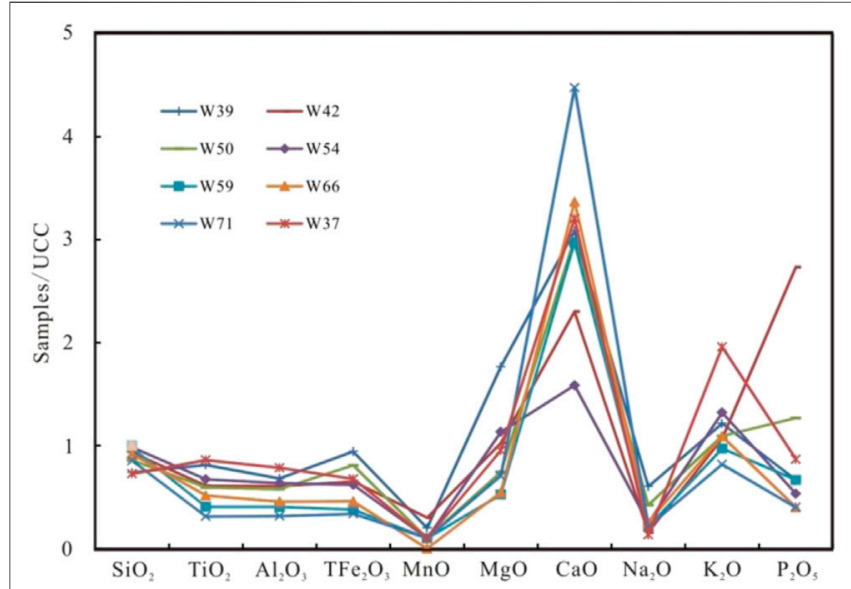

FIGURE 5 | UCC-normalized diagram of major elements of the Wulalike shale samples.

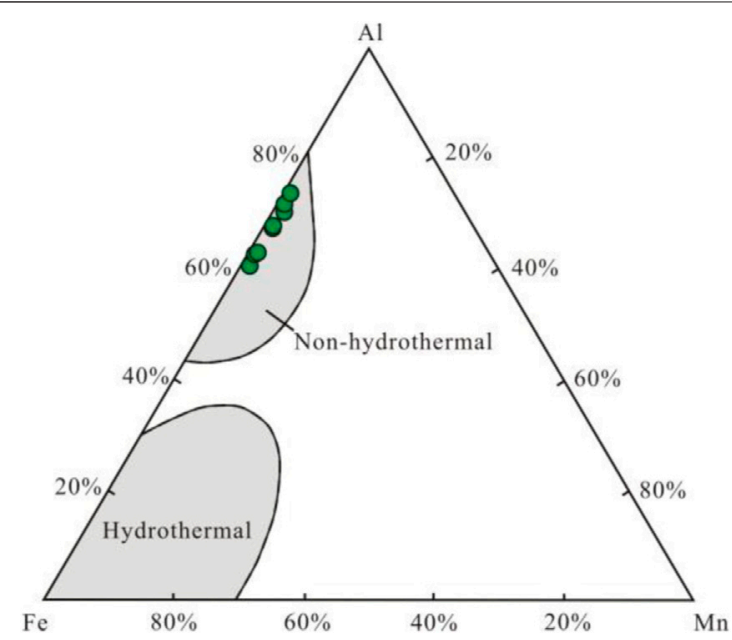

FIGURE 6 | Diagrams of the siliceous hydrothermal origins of the shale samples.

resolution at $12 \mathrm{~nm}$. Using the Quantax 200 XFlash X-ray spectrometer, the element composition of point scanning, line scanning, and area scanning are analyzed, and then the mineral composition in the samples is identified. The detector area is $150 \mathrm{~mm}^{2}$ and the resolution is $200 \mathrm{eV}$.

\section{RESULTS}

\section{Petrographic Characteristics}

The lithology of the Wulalike Formation is black mediumthick-bearing graptolite shale. The graptolites are developed on the shale horizon with different sizes in veinlets, short lines, and irregular shapes. The small ones are only $20-30 \mu \mathrm{m}$, and the large ones are several centimeters (Figure 3A). Pyrite can be seen in many places on the rock horizon (Figure 3B), covering the rock horizon with the form of stars and thin films, and the size ranges from $2 \mathrm{~mm}$ to $1 \mathrm{~cm}$, which indicates that the environment was reduced during deposition. The horizontal beddings distributed along the bedding plane are developed in the shale (Figure 3C). The bedding is fine and dense and the layer is thin, which indicates that the hydrodynamic condition is weak during the sedimentation of the Wulalike Formation. The shale was deposited in a relatively static and deeper water environment, with fractures developed in the shale (Figure 3D). The width of fractures ranges from $0.1 \mathrm{~mm}$ to several millimeters, and some fractures are distributed along the bedding plane, while others are at a certain angle with the bedding plane. However, it shows that the content of brittle minerals is high in the shale.

\section{Quartz Types}

It is found that the quartz has three forms in the shale under the microscope: biogenic quartz, microcrystalline quartz, and detrital quartz. Biogenic quartz mainly exists in the organisms of sponge spicules, radiolarias, and algae, and the organisms are filled with cryptocrystalline and microcrystalline quartz. The middle coelom of radiolaria is rounded and oval, and the lateral needling is bifurcated. The intact ones are few, and most of them are destroyed (Figure 4A). Some of them only have the middle coelom, which is filled with organic matter, and some of them only have radial needling (Figure $4 \mathbf{B}$ ). The intact ones are between 500 and $800 \mu \mathrm{m}$. Sponges are in various shapes, including single shot, double shot, triple shot, and so on (Figure 4C,D), with a length of $300-800 \mu \mathrm{m}$ and a diameter of about $30 \mu \mathrm{m}$. Algae are round in shape (Figure 4E), with particle sizes ranging from 200 to $500 \mu \mathrm{m}$, and some of the 

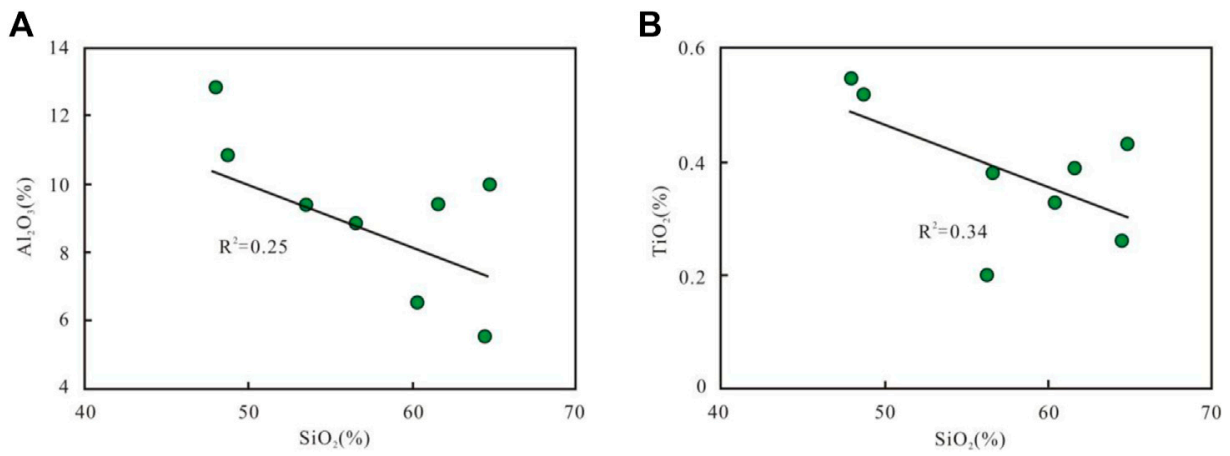

FIGURE 7 | (A) Negative correlation between $\mathrm{SiO}_{2}$ and $\mathrm{Al}_{2} \mathrm{O}_{3}$ contents. (B) Negative correlation between $\mathrm{SiO}_{2}$ and $\mathrm{TiO}_{2}$ contents.

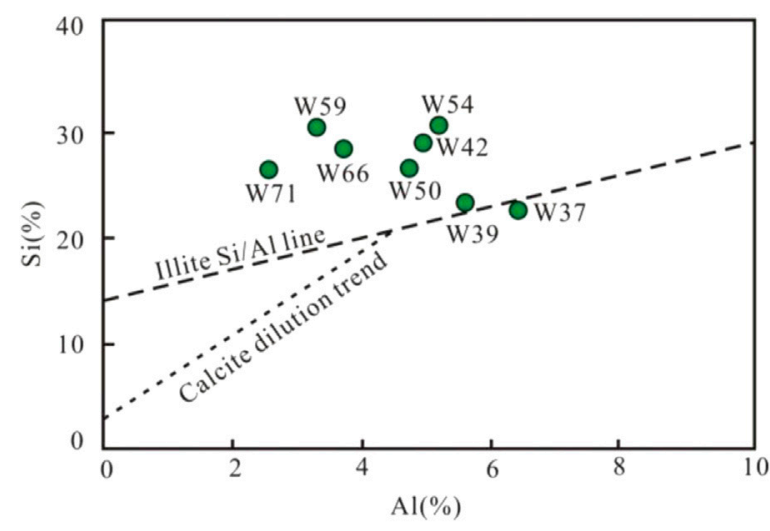

FIGURE 8 | Correlation between Al and Si contents.

outermost layers are surrounded by organic matter (Figure 4F). Microcrystalline quartz has no fixed morphology and is mainly distributed in shale pores as cement, which has a blue-green color in cross-polarized light (Figure 4G). The content of detrital quartz is less in the bottom of the Wulalike Formation and distributed in the shale matrix with a floating form. The content in the upper part of the Wulalike formation is higher. Most of the quartz grains are subangular, with a size of about 20-100 $\mu \mathrm{m}$ (Figure 4H).

\section{Organic Matter Abundance}

TOC is the most important indicator of organic matter abundance (Peters, 1986). The TOC content of shale in the Wulalike Formation is generally low, ranging from 0.70 to $1.30 \%$, with an average of $1.03 \%$ (Table 1 ).

\section{The Geochemistry of Major Elements}

The results of major elements are given in Table $\mathbf{1} . \mathrm{SiO}_{2}$ is the most abundant major element, ranging from 47.95 to $64.82 \%$, with an average of $57.60 \% . \mathrm{Al}_{2} \mathrm{O}_{3}$ is the second most abundant major element with a range of $4.86 \%-12.08 \mathrm{wt} \%$ (averaging $8.63 \mathrm{wt} \%)$. The contents of other elements such as $\mathrm{TiO}_{2}$, $\mathrm{TFe}_{2} \mathrm{O}_{3}, \mathrm{MnO}, \mathrm{MgO}, \mathrm{CaO}, \mathrm{Na}_{2} \mathrm{O}, \mathrm{K}_{2} \mathrm{O}$, and $\mathrm{P}_{2} \mathrm{O}_{5}$ are relatively low. Compared with the values of the upper continental crust (UCC) (Mclennan, 2001), most of the major elements are depleted, such as $\mathrm{SiO}_{2}, \mathrm{TiO}_{2}, \mathrm{Al}_{2} \mathrm{O}_{3}, \mathrm{TFe}_{2} \mathrm{O}_{3}, \mathrm{MgO}$, and $\mathrm{P}_{2} \mathrm{O}_{5}$, with the strongly depleted major elements being $\mathrm{MnO}$ and $\mathrm{Na}_{2} \mathrm{O}$, and only $\mathrm{CaO}$ is strongly enriched (Table 1; Figure 5).

\section{DISCUSSION}

\section{Origin of Silica}

Geochemical Analysis of Siliceous Source

Wedepohl (1971), Adachi et al. (1986), and Yamamoto (1987) proposed the $\mathrm{Al}-\mathrm{Fe}-\mathrm{Mn}$ triangle method to determine whether the siliceous minerals are from hydrothermal or nonhydrothermal areas. All samples are located in the nonhydrothermal area (Figure 6), indicating that there is no significant hydrothermal source in the study area.

The ratio of some elements is an effective method to determine the origin of siliceous minerals (Murray, 1994). Generally speaking, the $\mathrm{Al} /(\mathrm{Al}+\mathrm{Fe}+\mathrm{Mn})<0.35,(\mathrm{Fe}+\mathrm{Mn}) \mathrm{Ti}>25$ $( \pm 5)$, and $\mathrm{Fe} / \mathrm{Ti}>20$ in hydrothermal deposits (Murray, 1994; Harris et al., 2011; Qiu et al., 2020). The average values of $\mathrm{Al} /(\mathrm{Al}+$ $\mathrm{Fe}+\mathrm{Mn}),(\mathrm{Fe}+\mathrm{Mn}) \mathrm{Ti}$, and $\mathrm{Fe} / \mathrm{Ti}$ are $0.68,0.56$, and 9.41, respectively, which are all far less than that of hydrothermal deposits (Table 5) and shows that there is no obvious hydrothermal effect in the Wulalike Formation shale.

$\mathrm{Al}$ and $\mathrm{Ti}$ are often used to represent terrigenous flux (Saito et al., 1992; Fu et al., 2015; Zhao et al., 2021). The $\mathrm{SiO}_{2}$ of the samples has a weak negative correlation with $\mathrm{Al}_{2} \mathrm{O}_{3}$ and $\mathrm{TiO}_{2}$ (Figures 7A,B), indicating that terrigenous detrital quartz is not the main source of $\mathrm{SiO}_{2}$ and there may be other sources of $\mathrm{SiO}_{2}$. Rowe et al. (2008) fitted the illite Si/Al line according to the content of silicon and aluminum in the Barnett Shale. In the cross plot of $\mathrm{Si}$ and $\mathrm{Al}$, there is excess silicon above the illite Si/Al line that represented the biogenic silica (Zhao et al., 2016; Dong et al., 2019). The deeper depth of samples in the study area falls above the $\mathrm{Si} / \mathrm{Al}$ line, indicating that biogenic quartz is dominant, while the shallower samples W37 and W39 are closed to the Si/Al line or even located below the $\mathrm{Si} / \mathrm{Al}$ line, indicating that the two samples have a relatively higher detrital silica content (Figure 8). According to the above element geochemical analysis, the Wulalike Formation shale is not affected by the hydrothermal 

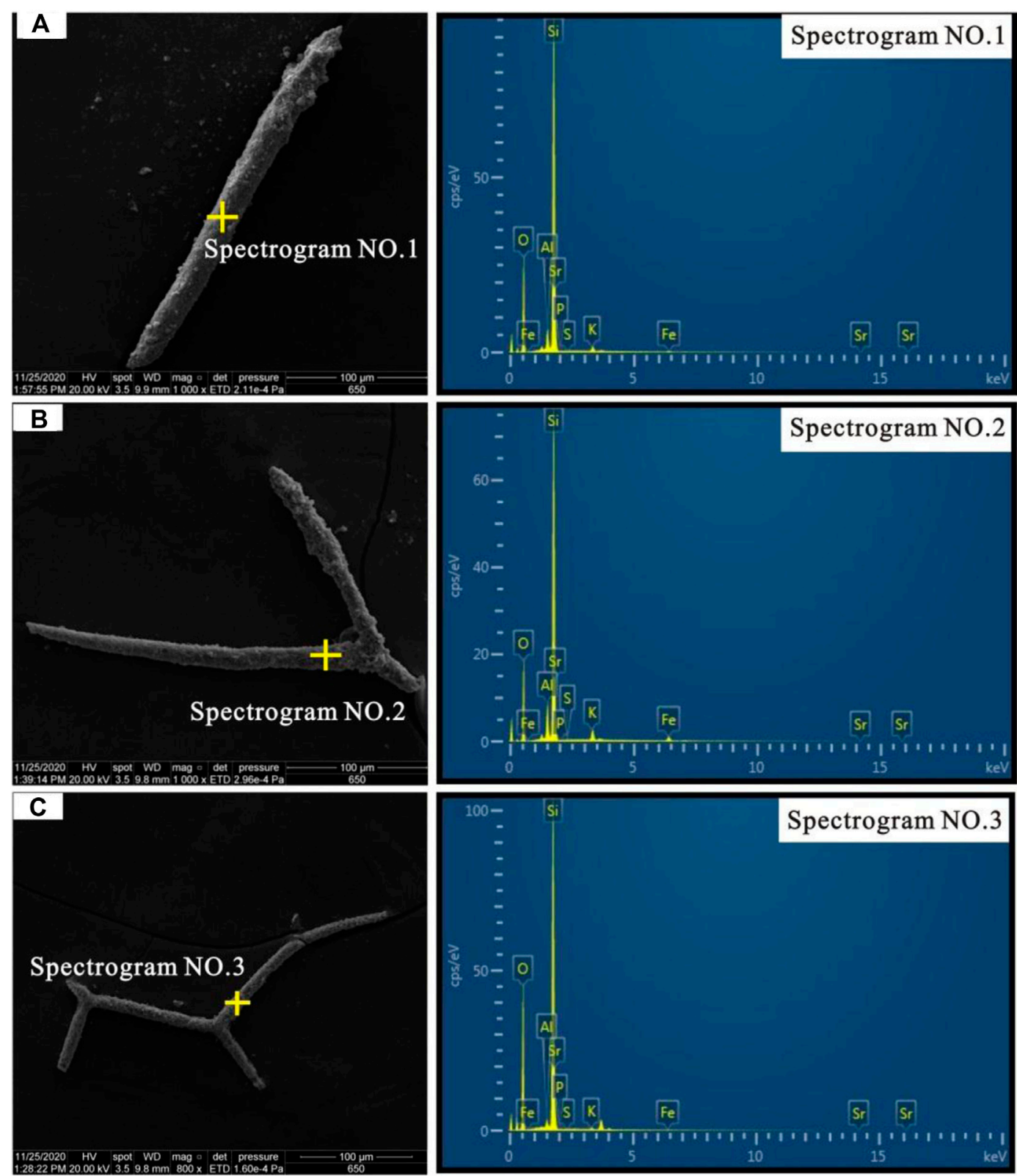

FIGURE 9 | Scanning electron microscope and energy spectrum analysis of sponges.

fluid. The siliceous source is biogenic silica and detrital silica in the study area. The biogenic silica is the main source at the bottom of the Wulalike Formation, while the content of detrital silica increases upward to the Wulalike Formation.

\section{Petrographic Analysis of Siliceous Source}

Microscopic observation shows a large number of siliceous organisms at the bottom of the Wulalike Formation, mainly radiolarians, sponge spicules, and algae, which are also strong evidence for biogenic silica. Scanning electron microscopy and the energy dispersive spectrometer analysis of some micropaleontology show that sponge spicules are mainly composed of silicon and oxygen (Figure 9). This further confirms the existence of biogenic silica in shale. Biogenic quartz is formed by plankton deposition with siliceous crust. At first, the silica is deposited as opal A, and then opal A dissolves to opal CT. Finally, with the time pass, opal CT transforms into cryptocrystalline and microcrystalline quartz and becomes the stable quartz in diagenetic facies (Boggs, 2006; Milliken et al., 2012; Yang et al., 2018). Through thin section observation, the content of detrital quartz gradually increases upward of the Wulalike Formation. In summary, petrographic observation and geochemical methods reveal that the Wulalike Formation shale is not affected by hydrothermal and the 
TABLE 2 | The derived and geochemical parameters of the shale samples.

\begin{tabular}{|c|c|c|c|c|c|c|}
\hline Sample ID & $\operatorname{Depth}(m)$ & Biogenic $\mathrm{SiO}_{2}(\%)$ & Detrital $\mathrm{SiO}_{2}(\%)$ & $A l /(A l+F e+M n)$ & $(F e+M n) T i$ & $\mathrm{Fe} / \mathrm{Ti}$ \\
\hline W37 & $4,726.10$ & 5.33 & 42.62 & 0.73 & 0.79 & 7.23 \\
\hline W39 & $4,738.65$ & 11.77 & 36.98 & 0.62 & 1.04 & 10.66 \\
\hline W42 & $4,740.55$ & 28.62 & 32.95 & 0.68 & 0.54 & 9.81 \\
\hline W50 & $4,746.82$ & 25.20 & 31.37 & 0.62 & 0.65 & 12.50 \\
\hline W54 & $4,748.84$ & 30.28 & 34.54 & 0.70 & 0.57 & 8.47 \\
\hline W59 & $4,751.73$ & 42.41 & 22.02 & 0.71 & 0.21 & 8.57 \\
\hline W66 & $4,754.43$ & 35.63 & 24.77 & - & - & 8.17 \\
\hline W71 & $4,757.34$ & 39.14 & 17.15 & 0.68 & 0.14 & 9.92 \\
\hline Avg & & 27.30 & 30.30 & 0.68 & 0.56 & 9.41 \\
\hline
\end{tabular}

siliceous minerals are mainly biogenic silica and terrigenous detrital silica.

\section{Quantitative Calculation of Different Origin Silica}

Holdaway and Clayton (1982) proposed that excess silica is, except normal terrigenous, detrital from siliceous minerals and is calculated applying the following formula: $\left(\mathrm{Si}_{\mathrm{xs}}=\mathrm{Si}_{\mathrm{total}^{-}}\right.$ $\left.\left[\mathrm{Al}_{\text {sample }} \times(\mathrm{Si} / \mathrm{Al})_{\text {PAAS }}\right]\right)$, where $\mathrm{Si}_{\text {total }}$ and $\mathrm{Al}_{\text {sample }}$ are the total contents of $\mathrm{Si}$ and $\mathrm{Al}$ in the sample, respectively. $(\mathrm{Si} / \mathrm{Al})_{\mathrm{PAAS}}$ is $\mathrm{Si} /$ $\mathrm{Al}$ in PAAS, which is 3.11 (Wedepohl, 1971). The biogenic silica and detrital silica of the Wulalike Formation are calculated in Table 2, in which the detrital silica is equal to the total silica minus the biogenic silica. According to the calculation (Table 2), the content of biogenic silica is higher than that of detrital silica in the shale at the bottom of the Wulalike Formation, and the content of detrital silica is higher than that of biogenic silica, which gradually changes to upward of the Wulalike Formation.

In this study, all the samples are from the bottom of the Wulalike Formation. The vertical variation of different genetic silica contents of the Wulalike Formation is comprehensively studied from the elements logging data ( $\mathrm{Si}$ and $\mathrm{Al}$ ) of well $\mathrm{A}$ provided by the Changqing Oilfield Company. The above formula was used to calculate the different genetic silica contents in well A. In the bottom of the Wulalike Formation, the biogenic silica content is higher than that of the detrital silica (Figure 10). Upward, the detrital silica gradually increases and the biogenic silica decreases (Figure 10).

\section{Relationship Between Biogenic Silica and Organic Matter}

Paleoproductivity refers to the total amount of organic matter fixed per unit area per unit time (Algeo et al., 2011; Pan et al., 2020). Generally speaking, high organic productivity is one of the key factors for the formation of hydrocarbon source rocks (Talbot, 1988; Nelson et al., 1995; Mansour et al., 2020a; Mansour et al., 2020b; Yang et al., 2016; Zhao et al., 2021), and a large number of studies have shown that siliceous plankton in marine source rocks is the main provider of marine primary productivity (De Wever and Baudin, 1996; Chou et al., 2012; Xiang et al., 2013; Shaldybin et al., 2017; Jiang et al., 2019; Zhang et al., 2019), whose content is closely related to the biological reproduction in surface water, and its temporal and spatial distribution can be used to reflect the changing process of paleoproductivity. In recent years, many studies have shown that radiolarians enriched in marine hydrocarbon source rocks can gather together and absorb a lot of symbiotic algae in their bodies by using a large number of pseudopodia, forming a good symbiotic relationship with them (Lyle et al., 1988; Erbacher and Thurow, 1997; Xiang et al., 2013; Khan et al., 2019). Globally, most siliceous formations are radiolarites, which are excellent hydrocarbon source rocks. For example, the Devonian Domanik layer in Russia is composed of radiolarian-rich siliceous mudstone (Ormistron, 1993; Afanasieva, 2000), and in Northwest China, large numbers of giant oil fields located in the Tarim Basin are composed of organic-rich sedimentary strata of siliceous rocks containing radiolarians (Sun et al., 2003). Additionally, the lower Cambrian Niutitang Formation (Zhang et al., 2007) and the upper Permian Dalong Formation are marine source rocks rich in radiolarian fossils (Xia et al., 2010).

Therefore, the enrichment of radiolarians can directly represent the marine primary productivity. Radiolarians are marine floating unicellular animals with delicate siliceous skeletons, and the lipid contents can reach as high as $47 \%$ (Anderson, 1983; De Wever et al., 2001; Du et al., 2012). In silicified zooplankton and phytoplankton, there is a large amount of organic matter in the skeletons, which can promote the increase of organic matter in sedimentary rocks (Lampitt et al., 2009; Dennett et al., 2002; Zhao et al., 2016). Therefore, the high content of biogenic silica in shale represents that the marine paleoproductivity was high during deposition, and the corresponding hydrocarbon generating organisms were flourishing, which was more favorable for the enrichment of organic matter. TOC is positively correlated with the $\mathrm{SiO}_{2}$ of well $\mathrm{A}$ in the study area (Figure 11A). A further study shows that TOC is positively correlated with biogenic silica and negatively correlated with detrital silica (Figures 11B,C), showing that biogenic silica plays a positive role in the enrichment of organic matter and the enrichment of organic matter may be related to paleoproductivity. Previous research works (Yang et al., 2016; Dong et al., 2019; Khan et al., 2019; Xu 


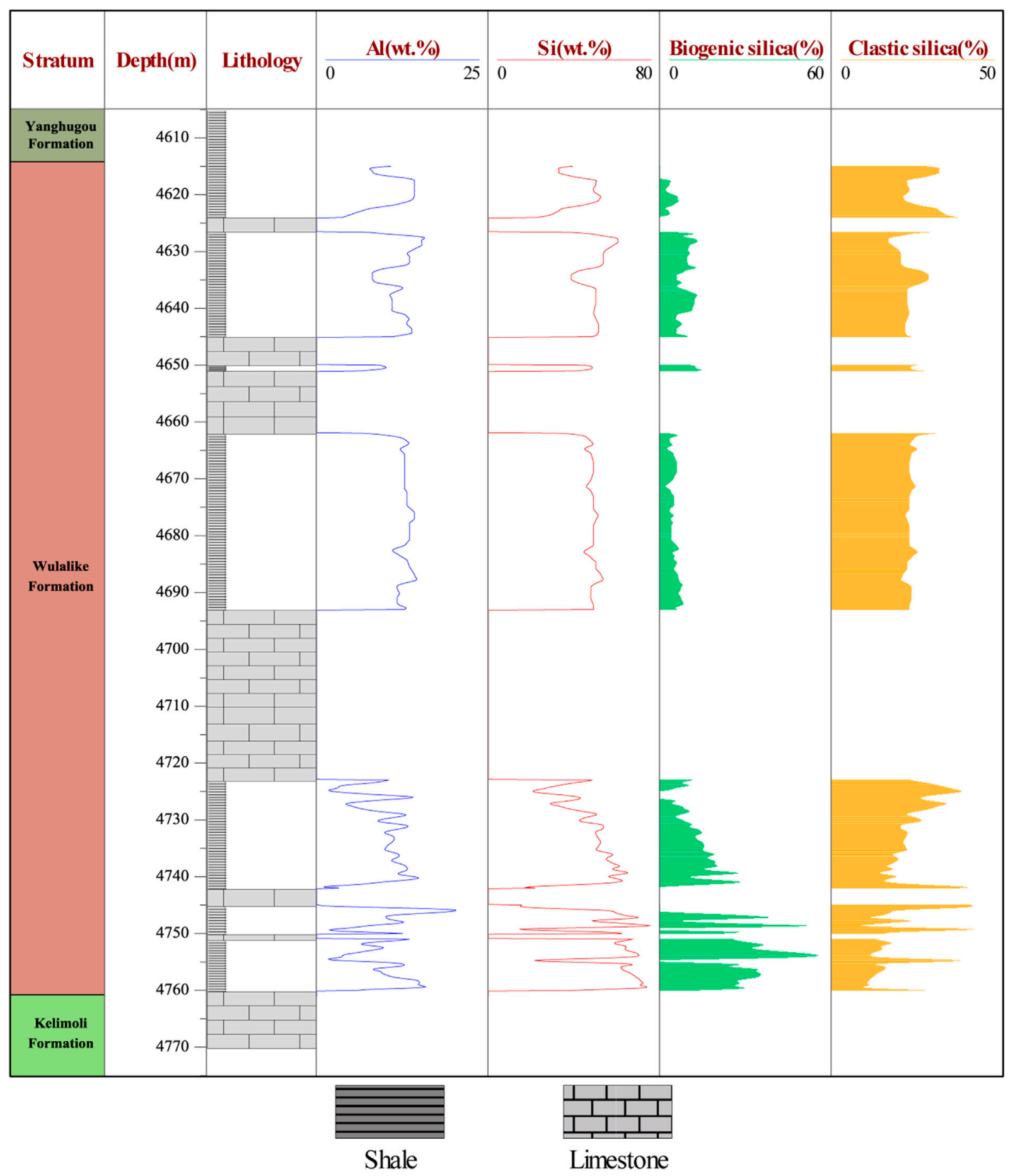

FIGURE 10 | Siliceous mineral origin from the well A in the Wulalike formation (location given in Figure 1B).

et al., 2019) show that the biogenic silica in shale is mainly developed in the lower Wufeng-Longmaxi Formation in the Sichuan Basin, and the content of total organic carbon in the lower part is significantly higher than that in the upper. The main gas producing reservoir of shale is located in the lower
Wufeng-Longmaxi Formation. According to the results of siliceous content of different genesis in the whole well A, biogenic silica is mainly distributed at the bottom of the Wulalike Formation. In addition, biogenic silica is positively correlated with TOC, so the TOC content at the 

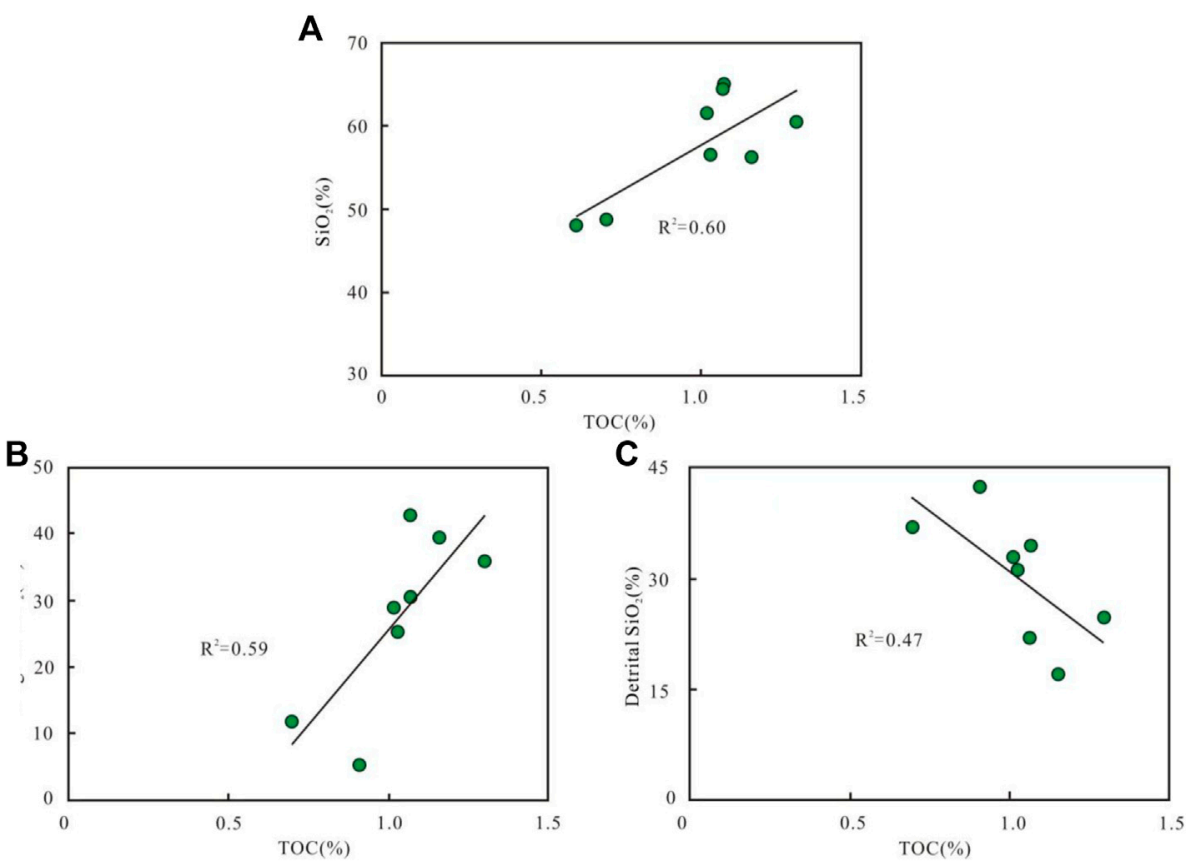

FIGURE 11 | Correlation diagrams of $\mathrm{SiO}_{2}$ and TOC contents. (A) The positive correlation between $\mathrm{SiO}_{2}$ and $\mathrm{TOC}$. (B) The positive correlation between biogenic $\mathrm{SiO}_{2}$ and TOC. (C) The negative correlation between detrital $\mathrm{SiO}_{2}$ and TOC.

bottom of the Wulalike Formation may be significantly higher than that at the upper part.

\section{Effect of Quartz on Shale Reservoir Quality}

Brittle minerals such as quartz, feldspar, and calcite in the shale reservoir are the main factors controlling the development of shale fractures. For the shale in commercial development conditions, the content of brittle minerals such as quartz is generally higher than $40 \%$, and the content of clay minerals is less than 30\% (Bowker, 2007; Ross and Bustin, 2009). Quartz is the main brittle mineral in shale, and its content often determines the brittleness and fracturing of shale gas reservoirs. The higher the quartz content, the greater the brittleness and the better the fracturing. It is found that different types of quartz have different mechanical properties, and it is almost impossible to produce brittle behavior for the detrital quartz dispersed in a shale matrix (Milliken and Olson, 2017; Huang et al., 2020a; Liu et al., 2020), while biogenic microcrystalline quartz can form an interconnected rigid framework, which can improve the hardness and brittleness of shale (Dong et al., 2017; Milliken and Olson, 2017; Liu et al., 2020). Meanwhile, biogenic microcrystalline quartz can protect organic matter pores from mechanical compaction (Schieber, 2011; Fishman et al., 2012; Gao et al., 2020; Yang et al., 2020). Therefore, it is of great significance to pay attention to the high content of biogenic silica in shale for shale gas exploitation. The content of biogenic silica is high at the bottom of well A (Figure 10), so the shale gas may be easier to fracture at the bottom of the Wulalike Formation in well A.

\section{CONCLUSION}

1) Geochemical indexes and petrographic observation of well $A$ in the Ordos Basin show that the source of silica in the Wulalike shale is mainly biogenic silica and detrital silica, without being affected by hydrothermal silica. Biogenic silica is the dissolution and recrystallization of siliceous plankton during burial and the formation of stable cryptocrystalline or microcrystalline aggregates after diagenesis. The detrital quartz is mainly transported to the basin by fluvial processes.

2) TOC in shale is positively correlated with biogenic silica and negatively correlated with detrital silica. Biogenic silica is an important indicator of paleoproductivity, indicating that paleoproductivity is one of the main factors controlling the organic matter enrichment of the Wulalike Formation shale.

3) Different genetic quartz has different mechanical properties. Biogenic microcrystalline quartz can form an interconnected rigid framework to improve the hardness and brittleness of shale. At the same time, biogenic microcrystalline quartz can protect organic pores from mechanical compaction. Through the quantitative calculation of different genetic silica in the whole well $\mathrm{A}$, it is found that biogenic silica mainly exists in the bottom of the Wulalike Formation and the detrital silica content increases gradually upward. The TOC content may be higher than in the upper part, and the bottom of the Wulalike shale and is more conducive to fracturing for shale gas exploration. The next exploration target in the northwest margin of the Ordos Basin should be concentrated at the bottom of the Wulalike Formation. 


\section{DATA AVAILABILITY STATEMENT}

The original contribution presented in the study is included in the article/Supplementary Material; further inquiries can be directed to the corresponding author.

\section{AUTHOR CONTRIBUTIONS}

YZ: conceptualization, methodology, writing-original draft, and software. RL: methodology and supervision. HH: resources, investigation, and validation. TG: formal analysis. LC: writing-review and editing. BZ: investigation and validation. XW: investigation. AK: investigation. All authors read and approved the manuscript.

\section{REFERENCES}

Adachi, M., Yamamoto, K., and Sugisaki, R. (1986). Hydrothermal Chert and Associated Siliceous Rocks from the Northern Pacific Their Geological Significance as Indication Od Ocean ridge Activity. Sediment. Geology. 47, 125-148. doi:10.1016/0037-0738(86)90075-8

Afanasieva, M. S. (2000). Atlas of Paleozoic Radiolaria of the Russian Platform. Moscow: Nauchnyi Mir, 477. (in Russian).

Algeo, T. J., Kuwahara, K., Sano, H., Bates, S., Lyons, T., Elswick, E., et al. (2011). Spatial Variation in Sediment Fluxes, Redox Conditions, and Productivity in the Permian-Triassic Panthalassic Ocean. Palaeogeogr. Palaeoclimatol. Palaeoecol. 308, 65-83. doi:10.1016/ j.palaeo.2010.07.007

Anderson, O. R. (1983). The Trophic Role of Planktonic Foraminifera and Radiolarian. Mar. Microb. Food Webs 7, 31-51.

Beauchamp, B., and Baud, A. (2002). Growth and Demise of Permian Biogenic Chert along Northwest Pangea: Evidence for End-Permian Collapse of Thermohaline Circulation. Palaeogeogr. Palaeoclimatol. Palaeoecol. 184, 37-63. doi:10.1016/S0031-0182(02)00245-6

Boggs, J. S. (2006). Application of Cathodoluminescence Imaging to the Study of Sedimentary Rocks. Cambridgeshire, England: Cambridge University Press, 177.

Bowker, K. A. (2007). Barnett Shale Gas Production, Fort Worth Basin: Issues and Discussion. Bulletin 91, 523-533. doi:10.1306/06190606018

Campbell, A. C., Palmer, M. R., Klinkhammer, G. P., Bowers, T. S., Edmond, J. M., Lawrence, J. R., et al. (1988). Chemistry of hot springs on the Mid-Atlantic Ridge. Nature 335, 514-519. doi:10.1038/335514a0

Chen, L., Jiang, Z., Liu, Q., Jiang, S., Liu, K., Tan, J., et al. (2019a). Mechanism of Shale Gas Occurrence: Insights from Comparative Study on Pore Structures of marine and Lacustrine Shales. Mar. Pet. Geology. 104, 200-216. doi:10.1016/ j.marpetgeo.2019.03.027

Chen, L., Liu, K., Jiang, S., Huang, H., Tan, J., and Zuo, L. (2021). Effect of Adsorbed Phase Density on the Correction of Methane Excess Adsorption to Absolute Adsorption in Shale. Chem. Eng. J. 420, 127678. doi:10.1016/ j.cej.2020.127678

Chen, L., Zuo, L., Jiang, Z., Jiang, S., Liu, K., Tan, J., et al. (2019b). Mechanisms of Shale Gas Adsorption: Evidence from Thermodynamics and Kinetics Study of Methane Adsorption on Shale. Chem. Eng. J. 361, 559-570. doi:10.1016/ j.cej.2018.11.185

Chou, Y., Lou, J. Y., Chen, C.-T. A., and Liu, L.-L. (2012). Spatial Distribution of Sponge Spicules in Sediments Around Taiwan and the Sunda Shelf. J. Oceanogr. 68, 905-912. doi:10.1007/s10872-012-0143-7

Day-Stirrat, R. J., Milliken, K. L., Dutton, S. P., Loucks, R. G., Hillier, S., Aplin, A. C., et al. (2010). Open-system Chemical Behavior in Deep Wilcox Group Mudstones, Texas Gulf Coast, USA. Mar. Pet. Geology. 27, 1804-1818. doi:10.1016/j.marpetgeo.2010.08.006

Dennett, M. R., Caron, D. A., and Michaels, A. F. (2002). Video Plankton Recorder Reveals High Abundances of Colonial Radiolaria in Surface Waters of the

\section{FUNDING}

This study was supported by the National Natural Science Foundation of China (No. 41772118), the China Postdoctoral Science Foundation (Nos. 2019M663918XB and 2020M682262), the Natural Science Basic Research Program of Shaanxi (No. 2021JQ-226), and the Fundamental Research Funds for Central Universities, CHD (No. 300102270108).

\section{ACKNOWLEDGMENTS}

The authors want to thank Lujun Lin for his data collection.

central North Pacific. J. Plankton Res. 24, 797-805. doi:10.1117/ 12.72679410.1093/plankt/24.8.797

De Wever, P., and Baudin, F. (1996). Palaeogeography of Radiolarite and OrganicRich Deposits in Mesozoic Tethys. Geol. Rundsch. 85, 310-326. doi:10.1007/ BF02422237

De Wever, P., Dumitrica, P., Caulet, J. P., Nigrini, C., and Caridroit, M. (2001). Radiolarians in the Sedimentary Record New York, NY: Gordon and Breach Science Publishers, 29-76.

Dong, T., Harris, N. B., Ayranci, K., and Yang, S. (2017). The Impact of Rock Composition on Geomechanical Properties of a Shale Formation: Middle and Upper Devonian Horn River Group Shale, Northeast British Columbia, Canada. Bulletin 101, 177-204. doi:10.1306/07251615199

Dong, T., and Harris, N. B. (2020). The Effect of thermal Maturity on Porosity Development in the Upper Devonian-Lower Mississippian Woodford Shale, Permian Basin, US: Insights into the Role of Silica Nanospheres and Microcrystalline Quartz on Porosity Preservation. Int. J. Coal Geology. 217, 1-14. doi:10.1016/j.coal.2019.103346

Dong, T., He, S., Chen, M., Hou, Y., Guo, X., Wei, C., et al. (2019). Quartz Types and Origins in the Paleozoic Wufeng-Longmaxi Formations, Eastern Sichuan Basin, China: Implications for Porosity Preservation in Shale Reservoirs. Mar. Pet. Geology. 106, 62-73. doi:10.1016/j.marpetgeo.2019.05.002

Du, Y., Jun, S., and Feng, Q. (2012). Applications of Radiolarians for Productivity and Hydro-Carbon-Source Rock. J. Earth Sci. 37, 147-155. (in Chinese with English abstract). doi:10.3799/dqkx.2012.S2.015

Erbacher, J., and Thurow, J. (1997). Influence of Oceanic Anoxic Events on the Evolution of Mid-cretaceous Radiolaria in the North Atlantic and Western Tethys. Mar. Micropaleontology 30, 139-158. doi:10.1016/S0377-8398(96) 00023-0

Fishman, N. S., Hackley, P. C., Lowers, H. A., Hill, R. J., Egenhoff, S. O., Eberl, D. D., et al. (2012). The Nature of Porosity in Organic-Rich Mudstones of the Upper Jurassic Kimmeridge Clay Formation, north Sea, Offshore United Kingdom. Int. J. Coal Geology. 103, 32-50. doi:10.1016/ j.coal.2012.07.012

Fu, J. H., and Zheng, C. B. (2001). Evolution between North China Sea and Qilian Sea of the Ordovician and the Characteristics of Lithofacies Palaeogeography in Ordos basin. J. Palaeogeogr. 4, 25-34. (in Chinese with English abstract).

Fu, X., Wang, J., Tan, F., Feng, X., Chen, W., Song, C., et al. (2015). Sr and Nd Isotopic Systematics of Mid-cretaceous Organic-Rich Rocks (Oil Shales) from the Qiangtang Basin: Implications for Source Regions and Sedimentary Paleoenvironment. Oil Shale 32, 109-123. doi:10.3176/oil.2015.2.02

Gao, Z., Fan, Y., Xuan, Q., and Zheng, G. (2020). A Review of Shale Pore Structure Evolution Characteristics with Increasing thermal Maturities. Adv. Geo-energy Res. 4, 247-259. doi:10.46690/ager.2020.03.03

Gou, Q., and Xu, S. (2019). Quantitative Evaluation of Free Gas and Adsorbed Gas Content of Wufeng-Longmaxi Shales in the Jiaoshiba Area, Sichuan Basin, China. Adv. Geo-energ. Res. 3, 258-267. doi:10.26804/ager.2019.03.04

Guan, Q. Z., Dong, D. Z., Zhang, H. L., Sun, S. S., Zhang, S. R., and Guo, W. (2021). Types of Biogenic Quartz and its Coupling Storage Mechanism in Organic-Rich Shales: A Case Study of the Upper Ordovician Wufeng Formation to Lower 
Silurian Longmaxi Formation in the Sichuan Basin, SW China. Pet. Exploration Develop. 48, 1-10. [in Chinese with English abstract]. doi:10.11698/ PED.2021.04.03

Guo, X. S. (2014). Rules of Two-Factor Enrichiment for marine Shale Gas in Southern China Understanding from the Longmaxi Formation Shale Gas in Sichuan basin and its Surrounding Area. Acta Geologica Sinica 88, 1209-1218. [in Chinese with English abstract]. doi:10.1111/17556724.12347

Harris, N. B., Miskimins, J. L., and Mnich, C. A. (2011). Mechanical Anisotropy in the Woodford Shale, Permian Basin: Origin, Magnitude, and Scale. The Leading Edge 30, 284-291. doi:10.1190/1.3567259

Harrover, R. D., Norman, D. I., Savin, S. M., and Sawkins, F. J. (1982). Stable Oxygen Isotope and Crystallite Size Analysis of the Cherts, De Long Mountains, Alaska; an Exploration Tool for Submarine Exhalative Deposits. Econ. Ceol. 77, 1761-1766. doi:10.2113/gsecongeo.77.7.1761

He, C., Ji, L., Wu, Y., Su, A., and Zhang, M. (2016). Characteristics of Hydrothermal Sedimentation Process in the Yanchang Formation, South Ordos Basin, China: Evidence from Element Geochemistry. Sediment. Geology. 345, 33-41. doi:10.1016/j.sedgeo.2016.09.001

Hein, J. R. (1987). Siliceous Sedimentary Rock-Hosted Ores and Petroleum. New York: Van Nostrand Reinhold Co.

Holdaway, H. K., and Clayton, C. J. (1982). Preservation of shell microstructure in silicified brachiopods from the upper cretaceous Wilmington sands of Devon. Geol. Mag. 119, 371-382. doi:10.1017/S0016756800026285

Hou, L., Luo, X., Lin, S., Zhao, Z., and Li, Y. (2021). Quantitative Measurement of Retained Oil in Organic-Rich Shale-A Case Study on the Chang 7 Member in the Ordos Basin, China. Front. Earth Sci. 9, 662586. doi:10.3389/ feart.2021.662586

Huang, H., Li, R., Jiang, Z., Li, J., and Chen, L. (2020a). Investigation of Variation in Shale Gas Adsorption Capacity with Burial Depth: Insights from the Adsorption Potential Theory. J. Nat. Gas Sci. Eng. 73, 103043. doi:10.1016/ j.jngse.2019.103043

Huang, H., Li, R., Xiong, F., Hu, H., Sun, W., Jiang, Z., et al. (2020b). A Method to Probe the Pore-Throat Structure of Tight Reservoirs Based on Low-Field NMR: Insights from a Cylindrical Pore Model. Mar. Pet. Geology. 117, 104344. doi:10.1016/j.marpetgeo.2020.104344

Jiang, T., Jin, Z., Liu, G., Liu, Q., Gao, B., Liu, Z., et al. (2019). Source Analysis of Siliceous Minerals and Uranium in Early Cambrian Shales, South China: Significance for Shale Gas Exploration. Mar. Pet. Geology. 102, 101-108. doi:10.1016/j.marpetgeo.2018.11.002

Joseph, F. E., Patrick, J. D., Kevin, G. T., Sarah, J. D., Christopher, H. V., Vicky, M. H., et al. (2020). Origin and Implications of Early Diagenetic Quartz in the Mississippian Bowland Shale Formation, Craven Basin, UK. Mar. Pet. Geology. 120, 1-15. doi:10.1016/j.marpetgeo.2020.104567

Khan, M. Z., Feng, Q., Zhang, K., and Guo, W. (2019). Biogenic Silica and Organic Carbon Fluxes Provide Evidence of Enhanced marine Productivity in the Upper Ordovician-Lower Silurian of South China. Palaeogeogr. Palaeoclimatol. Palaeoecol. 534, 109278. doi:10.1016/j.palaeo.2019.109278

Lampitt, R. S., Salter, I., and Johns, D. (2009). Radiolaria: Major Exporters of Organic Carbon to the Deep Ocean. Glob. Biogeochem. Cycles 23, a-n. doi:10.1029/2008GB003221

Lee, K. Y. (1986). Geology of the Coal and Petroleum Deposits in the Ordos Basin, China. Proceedings of SPIE-The International Society for Optical Engineering 6604, 131108. doi:10.1117/12.726794

Li, D., Li, R., Tan, C., Zhao, D., Xue, T., Zhao, B., et al. (2019). Origin of Silica, Paleoenvironment, and Organic Matter Enrichment in the Lower Paleozoic Niutitang and Longmaxi Formations of the Northwestern Upper Yangtze Plate: Significance for Hydrocarbon Explorationficance for Hydrocarbon Exploration. Mar. Pet. Geology. 103, 404-421. doi:10.1016/ j.marpetgeo.2019.02.025

Lin, C. S., Yang, Q., and Li, S. T. (1995). Analysis of Filling Evolution in Helan Aulacogon basin. Beijing: Geological Press, 48-60. (in Chinese).

Liu, B., Schieber, J., Mastalerz, M., and Teng, J. (2020). Variability of Rock Mechanical Properties in the Sequence Stratigraphic Context of the Upper Devonian new Albany Shale, Illinois basin. Mar. Pet. Geology. 112, 104068. doi:10.1016/j.marpetgeo.2019.104068

Liu, S., Ma, W., Jansa, L., Huang, W., Zeng, X., and Zhang, C. (2013). Characteristics of the Shale Gas Reservoir Rocks in the Lower Silurian
Longmaxi Formation, East Sichuan basin, China. Energy Exploration \& Exploitation 31, 187-219. doi:10.1260/0144-5987.31.2.187

Loucks, R. G., and Ruppel, S. C. (2007). Mississippian Barnett Shale: Lithofacies and Depositional Setting of a Deep-Water Shale-Gas Succession in the Fort Worth Basin, Texas. Bulletin 91, 579-601. doi:10.1306/11020606059

Lyle, M., Murray, D. W., Finney, B. P., Dymond, J., Robbins, J. M., and Brooksforce, K. (1988). The Record of Late Pleistocene Biogenic Sedimentation in the Eastern Tropical Pacific Ocean. Paleoceanography 3, 39-59. doi:10.1029/ PA003i001p00039

Ma, Z. R., Bai, H. F., Liu, B. X., Wang, H. W., and Chen, T. S. (2013). Lithofacies Palaeogeography of the Middle-Late Ordovician Kelimoli and Wulalike Ages in Western Ordos Area. J. Palaeogeogr. 15, 751-764. [in Chinese with English abstract]. doi:10.7605/gdlxb.2013.06.062

Mansour, A., Gentzis, T., Carvajal-Ortiz, H., Tahoun, S. S., and Wagreich, M. (2020b). Geochemistry and Palynology of the Upper Albian at the Abu Gharadig Basin, Southern Tethys: Constraints on the Oceanic Anoxic Event 1d. Geol. J. 55, 6338-6360. doi:10.1002/gj.3810

Mansour, A., Wagreich, M., Gentzis, T., Ocubalidet, S., Tahoun, S. S., and Elewa, A. M. T. (2020a). Depositional and Organic Carbon-Controlled Regimes during the Coniacian-Santonian Event: First Results from the Southern Tethys (Egypt). Mar. Pet. Geology. 115, 104285. doi:10.1016/j.marpetgeo.2020.104285

Mclennan, S. M. (2001). Relationships between the Trace Element Composition of Sedimentary Rocks and Upper continental Crust. Geochem. Geophys. Geosyst. 2, a-n. doi:10.1029/2000GC000109

Milliken, K. L., Ergene, S. M., and Ozkan, A. (2016). Quartz Types, Authigenic and Detrital, in the Upper Cretaceous Eagle Ford Formation, South Texas, USA. Sediment. Geology. 339, 273-288. doi:10.1016/j.sedgeo.2016.03.012

Milliken, K. L., Esch, W. L., Reed, R. M., and Zhang, T. (2012). Grain Assemblages and strong Diagenetic Overprinting in Siliceous Mudrocks, Barnett Shale (Mississippian), Fort Worth Basin, Texas. Bulletin 96, 1553-1578. doi:10.1306/12011111129

Milliken, K. L., and Olson, T. (2017). Silica Diagenesis, Porosity Evolution, and Mechanical Behavior in Siliceous Mudstones, Mowry Shale (Cretaceous), Rocky Mountains, U.S.A. J. Sediment. Res. 87, 366-387. doi:10.2110/ jsr.2017.24

Murray, R. W. (1994). Chemical Criteria to Identify the Depositional Environment of Chert: General Principles and Applications. Sediment. Geology. 90, 213-232. doi:10.1016/0037-0738(94)90039-6

Nelson, D. M., Tréguer, P., Brzezinski, M. A., Leynaert, A., and Quéguiner, B. (1995). Production and Dissolution of Biogenic Silica in the Ocean: Revised Global Estimates, Comparison with Regional Data and Relationship to Biogenic Sedimentation. Glob. Biogeochem. Cycles 9, 359-372. doi:10.1029/95gb01070

Ormistron, A. R. (1993). The Association of Radiolarians with the Hydrocarbon Source Rocks. New York, NY: Micropaleontology Special Publication, Radiolaria of giant and subgiant fields in Asia, 9-16.

Pan, X., Wang, Z., Li, Q., Gao, J., Zhu, L., and Liu, W. (2020). Sedimentary Environments and Mechanism of Organic Matter Enrichment of Dark Shales with Low TOC in the Mesoproterozoic Cuizhuang Formation of the Ordos Basin: Evidence from Petrology, Organic Geochemistry, and Major and Trace Elements. Mar. Pet. Geology. 122, 104695. doi:10.1016/ j.marpetgeo.2020.104695

Peters, K. E. (1986). Guidelines for Evaluating Petroleum Source Rock Using Programmed Pyrolysis. AAPG (Am. Assoc. Pet. Geol. Bull. 70, 318-329. doi:10.1306/94885688-1704-11D7-8645000102C1865D

Qiu, Z., Liu, B., Dong, D., Lu, B., Yawar, Z., Chen, Z., et al. (2020). Silica Diagenesis in the Lower Paleozoic Wufeng and Longmaxi Formations in the Sichuan Basin, South China: Implications for Reservoir Properties and Paleoproductivity. Mar. Pet. Geology. 121, 104594. doi:10.1016/ j.marpetgeo.2020.104594

Ritts, B. D., Hanson, A. D., Darby, B. J., Nanson, L., and Berry, A. (2004). Sedimentary Record of Triassic Intraplate Extension in North China: Evidence from the Nonmarine NW Ordos Basin, Helan Shan and Zhuozi Shan. Tectonophysics 386, 177-202. doi:10.1016/j.tecto.2004.06.003

Ross, D. J. K., and Marc Bustin, R. (2009). The Importance of Shale Composition and Pore Structure upon Gas Storage Potential of Shale Gas Reservoirs. Mar. Pet. Geology. 26, 916-927. doi:10.1016/j.marpetgeo.2008.06.004

Rowe, H. D., Loucks, R. G., Ruppel, S. C., and Rimmer, S. M. (2008). Mississippian Barnett Formation, Fort Worth Basin, Texas: Bulk Geochemical Inferences and 
Mo-TOC Constraints on the Severity of Hydrographic Restriction. Chem. Geology. 257, 16-25. doi:10.1016/j.chemgeo.2008.08.006

Saito, C., Noriki, S., and Tsunogai, S. (1992). Particulate Flux of A1, a Component of Land Origin, in the Western North Pacific. Deep Sea Res. A. Oceanographic Res. Pap. 39, 1315-1327. doi:10.1016/0198-0149(92)90071-Z

Schieber, J., Krinsley, D., and Riciputi, L. (2000). Diagenetic Origin of Quartz silt in Mudstones and Implications for Silica Cycling. Nature 406, 981-985. doi:10.1038/35023143

Schieber, J. (2011). Reverse Engineering Mother Nature - Shale Sedimentology from an Experimental Perspective. Sediment. Geology. 238, 1-22. doi:10.1016/ j.sedgeo.2011.04.002

Shaldybin, M. V., Lopushnyak, Y. M., Goncharov, I. V., Wilson, M. J., Wilson, L., and Mendis, B. G. (2017). The Mineralogy of the Clayey-Silty Siliceous Rocks in the Bazhenov Shale Formation (Upper Jurassic) in the West Siberian Basin, Russia: the Role of Diagenesis and Possible Implications for Their Exploitation as an Unconventional Hydrocarbon Reservoir. Appl. Clay Sci. 136, 75-89. doi:10.1016/j.clay.2016.11.009

Sun, S. L., Chen, J. F., and Liu, W. H. (2003). Hydrothermal Venting on the Seafloor and Formation of Organic-Rich Sediments Evidence from the Neoproterozoic Xiamaling Formation, North China. Geol. Rev. 49, 588-595. [in Chinese with English abstract]. doi:10.16509/j.georeview.2003.06.006

Talbot, M. R. (1988). The Origins of Lacustrine Oil Source Rocks: Evidence from the Lakes of Tropical Africa. Geol. Soc. Lond. Spec. Publications 40, 29-43. doi:10.1144/GSL.SP.1988.040.01.04

Wang, C., Wang, Q., Chen, G., He, L., Xu, Y., Chen, L., et al. (2017). Petrographic and Geochemical Characteristics of the Lacustrine Black Shales from the Upper Triassic Yanchang Formation of the Ordos Basin, China: Implications for the Organic Matter Accumulation. Mar. Pet. Geology. 86, 52-65. doi:10.1016/ j.marpetgeo.2017.05.016

Wang, R., Hu, Z., Long, S., Liu, G., Zhao, J., Dong, L., et al. (2019). Differential Characteristics of the Upper Ordovician-Lower Silurian Wufeng-Longmaxi Shale Reservoir and its Implications for Exploration and Development of Shale Gas In/around the Sichuan Basin. Acta Geologica Sinica - English Edition 93, 520-535. doi:10.1111/1755-6724.13875

Wang, R. Y., Hu, Z. Q., Dong, L., Gao, B., Sun, C. X., Yang, T., et al. (2021). Advancement and Trends of Shale Gas Reservoir Characterization and Evaluation. Oil Gas Geology. 42, 54-65. (in Chinese with English abstract). doi:10.11743/ogg20210105

Wang, R. Y., Nie, H. K., Hu, Z. Q., Liu, G. X., Xi, B. B., and Liu, W. X. (2020). Controlling Effect of Pressure Evolution on Shale Gas Reservoirs: A Case Study of the Wufeng-Longmaxi Formation in the Sichuan Basin. Nat. Gas Industry 40, 1-11. [in Chinese with English abstract]. doi:10.3787/j.issn.10000976.2020.10.001

Wang, S. C., Fu, S. T., Li, X. Z., Fu, J. H., Sun, F. J., and Jiang, Z. L. (2005). The Influence to the Accumulation of Oil and Gas of the Development of the Arcuate Structure Zone in the Transition Zone from the Plat to the Geosyncline in the West of Ordos Basin. Nat. Gas Geosci. 16, 421-427. doi:10.3969/ j.issn.1672-1926.2005.04.005

Wedepohl, K. H. (1971). Environmental Influences on the Chemical Composition of Shales and Claysfluences on the Chemical Composition of Shales and Clays. Phys. Chem. Earth 8, 307-333. doi:10.1016/00791946(71)90020-6

Wei, Y., Lu, S., Li, J., Yu, R., Li, W., Cheng, F., et al. (2021). Impacts of Gas Pressure on Carbon Isotope Fractionation during Methane Degassing-An Experimental Study on Shales from Wufeng and Longmaxi Formations in Southeast Sichuan, China. Mar. Pet. Geology. 128, 105001. doi:10.1016/ j.marpetgeo.2021.105001

Wu, D. X., Wu, X. N., Li, C. S., Yu, Z., Li, W. L., Cai, J., et al. (2020). Sedimentary Model and Hydrocarbon-Generation Potential of Source Rock of the Ordovician Wulalike Formation in Western Ordos Basin. Mar. Origin Pet. Geology. 26, 123-130. [in Chinese with English abstract]. doi:10.3969/ j.issn.1672-9854.2021.02.004

Wu, X. N., Sun, L. Y., Yu, Z., Ren, J. F., Ding, Z. C., and Huang, Z. L. (2015). Lithofacies Paleogeography of Ordovician in Western Ordos Basin. Lithologic Reservoirs 27, 87-96. doi:10.3969/j.issn.1673-8926.2015.06.012

Xia, M., Wen, L., Wang, Y., Hong, H., Fan, Y., and Wen, Y. (2010). High Quality Source Rocks in Trough Facies of Upper Permian Dalong Formation, Sichuan
Basin. Pet. Exploration Develop. 37, 654-662. [in Chinese with English abstract]. doi:10.1016/s1876-3804(11)60002-5

Xiang, Y., Feng, Q., Shen, J., and Zhang, N. (2013). Changhsingian Radiolarian Fauna from Anshun of Guizhou, and its Relationship to TOC and PaleoProductivity. Sci. China Earth Sci. 56, 1334-1342. doi:10.1007/s11430-0134615-4

Xiao, H., Zhao, J. Z., Xiong, T., Wu, W. T., Mi, J. K., and Liu, S. T. (2017). Evaluation of Ordovician Source Rocks and Natural Gas Accumulation Patterns in West Flank of a Paleo-Uplift, Ordos basin. Oil Gas Geology. 38, 1087-1097. doi:10.11743/ogg20170609

Xu, H., Zhou, W., Hu, Q., Yi, T., Ke, J., Zhao, A., et al. (2021). Quartz Types, Silica Sources and Their Implications for Porosity Evolution and Rock Mechanics in the Paleozoic Longmaxi Formation Shale, Sichuan Basin. Mar. Pet. Geology. 128, 105036. doi:10.1016/j.marpetgeo.2021.105036

Xu, L. M., Zhou, L. F., Zhang, Y. K., and Dang, B. (2006). Tectonic Stress Field Characteristics and Tectonic Background of the Ordos Basin. Geotectonica et Metallogenia 30, 455-462. [in Chinese with English abstract]. doi:10.16539/ j.ddgzyckx.2006.04.007

Xu, Z., Shi, W., Zhai, G., Clay, C., Zhang, X., and Peng, N. (2019). A Rock Physics Model for Characterizing the Total Porosity and Velocity of Shale: A Case Study in Fuling Area, China. Mar. Pet. Geology. 99, 208-226. doi:10.1016/ j.marpetgeo.2018.10.010

Yamamoto, K. (1987). Geochemical Characteristics and Depositional Environments of Cherts and Associated Rocks in the Franciscan and Shimanto Terranes. Sediment. Geology. 52, 65-108. doi:10.1016/00370738(87)90017-0

Yang, C., Xiong, Y., and Zhang, J. (2020). A Comprehensive Re-understanding of the OM-Hosted Nanopores in the marine Wufeng-Longmaxi Shale Formation in South China by Organic Petrology, Gas Adsorption, and X-ray Diffraction Studies. Int. J. Coal Geology. 218, 103362. doi:10.1016/ j.coal.2019.103362

Yang, F., Lyu, B., and Xu, S. (2021). Water Sorption and Transport in Shales: An Experimental and Simulation Study. Water Res. 57, 1-20. doi:10.1029/ 2019WR026888

Yang, F., Ning, Z., Wang, Q., Zhang, R., and Krooss, B. M. (2016). Pore Structure Characteristics of Lower Silurian Shales in the Southern Sichuan Basin, China: Insights to Pore Development and Gas Storage Mechanism. Int. J. Coal Geology. 156, 12-24. doi:10.1016/j.coal.2015.12.015

Yang, F., Xie, C., Ning, Z., and Krooss, B. M. (2017). High-pressure Methane Sorption on Dry and Moisture-Equilibrated Shales. Energy Fuels 31, 482-492. doi:10.1021/acs.energyfuels.6b02999

Yang, H., Tao, J. Q., Ouyang, Z. J., Li, G., and Jing, C. L. (2011). Structural Characteristics and Forming Mechanism in the Western Margin of the Ordos Basin. J. Northwest University:Natural Sci. Edition 41, 863-868. doi:10.1007/ s11708-010-0131-9

Yang, X. R., Yan, D. T., Wei, X. S., Zhang, L. W., Zhang, B., Xu, H. W., et al. (2018). Different Formation Mechanism of Quartz in Siliceous and Argillaceous Shales: A Case Study of Longmaxi Formation in South China. Mar. Pet. Geology. 94, 80-94. doi:10.1016/j.marpetgeo.2018.03.036

Zeng, L., Lyu, W., Zhang, Y., Liu, G., and Dong, S. (2021). The Effect of Multi-Scale Faults and Fractures on Oil Enrichment and Production in Tight sandstone Reservoirs: a Case Study in the Southwestern Ordos Basin, China. Front. Earth Sci. 9, 664629. doi:10.3389/feart.2021.664629

Zhang, K., Song, Y., Jiang, S., Jiang, Z., Jia, C., Huang, Y., et al. (2019). Mechanism Analysis of Organic Matter Enrichment in Different Sedimentary Backgrounds: A Case Study of the Lower Cambrian and the Upper Ordovician-Lower Silurian, in Yangtze Regionfferent Sedimentary Backgrounds: A Case Study of the Lower Cambrian and the Upper Ordovician-Lower Silurian, in Yangtze Region. Mar. Pet. Geology. 99, 488-497. doi:10.1155/2019/580602310.1016/ j.marpetgeo.2018.10.044

Zhang, L. W., Huang, J. H., Liang, Q., and Zhou, Y. (2007). Geological Characteristics and Ore prospect of the Black Layers in the Doushantuo and Niutitang Formations in Guizhou Province. Acta Mineral. Sin. 27, 456-460. [in Chinese with English abstract]. doi:10.16461/j.cnki.10004734.2007.z1.028

Zhao, B., Li, R., Qin, X., Wang, N., Zhou, W., Khaled, A., et al. (2021). Geochemical Characteristics and Mechanism of Organic Matter Accumulation of marine- 
continental Transitional Shale of the Lower Permian Shanxi Formation, southeastern Ordos Basin, North China. J. Pet. Sci. Eng. 205, 108815. doi:10.1016/j.petrol.2021.108815

Zhao, J. H., Jin, Z. J., Jin, Z. K., Win, X., Geng, Y. K., and Yan, C. N. (2016). The Genesis of Quartz in Wufeng-Longmaxi Gas Shales, Sichuan Basin. Nat. Gas Geosci. 27, 377-386. doi:10.11764/j.issn.1672-1926.2016.02.0377

Conflict of Interest: TG was employed by the PetroChina Changqing Oilfield Company

The remaining authors declare that the research was conducted in the absence of any commercial or financial relationships that could be construed as a potential conflict of interest.
Publisher's Note: All claims expressed in this article are solely those of the authors and do not necessarily represent those of their affiliated organizations, or those of the publisher, the editors, and the reviewers. Any product that may be evaluated in this article, or claim that may be made by its manufacturer, is not guaranteed or endorsed by the publisher.

Copyright () 2021 Zhang, Li, Huang, Gao, Chen, Zhao, Wu and Khaled. This is an open-access article distributed under the terms of the Creative Commons Attribution License (CC BY). The use, distribution or reproduction in other forums is permitted, provided the original author(s) and the copyright owner(s) are credited and that the original publication in this journal is cited, in accordance with accepted academic practice. No use, distribution or reproduction is permitted which does not comply with these terms. 